\title{
UJI ANTIOKSIDAN EKSTRAK ETANOL BUAH ASAM JAWA (TAMARINDUS INDICA L.) TUA DAN MUDA DENGAN METODE DPPH
}

\section{ANTIOXIDANT TEST OF OLD AND YOUNG TAMARIND FRUIT (TAMARINDUS INDICA L.) ETHANOL EXTRACT WITH DPPH METHOD}

\author{
Dwi Kartika Risfianty $^{1^{*}}$, Irna Il Sanuriza ${ }^{2}$ \\ ${ }^{1,2}$ Program Studi Biologi, Fakultas Matematika dan Ilmu Pengetahuan Alam, Universitas Nahdlatul Wathan, Mataram, \\ Indonesia \\ *Email: dkrisfianty@unwmataram.ac.id
}

Diterima: 28 Mei 2021. Disetujui: 21 Juni 2021. Dipublikasikan: 24 Agustus 2021

\begin{abstract}
Abstrak: Salah satu yang menjadi penyebab kematian terbesar di dunia adalah penyakit degenerative, bahkan di Indonesia terjadi peningkatan setiap tahunnya. Beberapa jenis penyakit degeneratif menempati peringkat 10 besar diantaranya: penyakit jantung, asam urat, diabetes mellitus, hipertensi dan lainnya memaksa penderita harus rawat inap ataupun rawat jalan di rumah sakit atau puskesmas, juga mengakibatkan penuaan dini karna adanya penurunan kolagen dan elastase pada kulit akibat terpapar radikal bebas. Penyakit ini tidak menular namun berlangsung kronis karna terjadinya kemunduran fungsi sel dan organ. Penyebabnya adalah radikal bebas dan juga dipengaruhi oleh gaya hidup. Mencegah efek negatif dari radikal bebas yakni dengan senyawa antioksidan. Buah asam jawa mengandung senyawa antioksidan. Penelitian ini bertujuan untuk menguji aktivitas antioksidan yang ada pada buah asam jawa muda dan tua, setelah itu membandingkan hasil dari keduanya. Metode yang digunakan dalam penelitian ini adalah metode uji DPPH untuk mengetahui seberapa tinggi aktivitas antioksidan (penangkapan radikal bebas) buah asam jawa muda dan tua. Hasil pengujian aktivitas antioksidan buah asam jawa muda dan tua menunjukkan bahwa buah asam jawa tua memiliki aktivitas antioksidan lebih tinggi yakni 85,28 \%, sedangkan buah asam jawa muda 78,87 \%..
\end{abstract}

Kata Kunci : aktivitas antioksidan, radikal bebas, penyakit degeneratif dan DPPH

\begin{abstract}
One of the biggest causes of death in the world is degenerative diseases, even in Indonesia which increases annually. Some kind of degenerative disease rank in the top 10 among them: heart disease, uric acid, diabetes mellitus, hypertension and others require hospitalization or hospitalization outpatient treatment at a hospital or medical center, also results premature aging due to a decline in collagen and elastic growth free radicalized skin. The disease is not contagious but chronic because of cellular dysfunction and organs. The cause is free radicals and also affected by lifestyle. Preventing the negative effects of free radicals with antioxidant compounds and tamarind fruits contain compounds The antioxidants. The aim of this study is to test activities Antioxidants on the tamarind fruits are young and old, after all comparing the results of both. Methods is used in this research is a DPPH method of testing to find out how high antioxidal activity tamarind fruits young and old. The test results of antioxidant activity young and old tamarind fruit indicates that old Javanese acid has the higher antioxidal activity is 85.28 , while the fruit young javanese acid $78.87 \%$.
\end{abstract}

Keywords : antioxidal activit, free radicals, degenerative disease dan DPPH

\section{PENDAHULUAN}

Salah satu yang menjadi penyebab kematian terbesar di dunia adalah penyakit degeneratif [1], bahkan di Indonesia terjadi peningkatan setiap tahunnya. Penyakit ini tidak menular namun berlangsung kronis karna terjadinya kemunduran fungsi sel dan organ karna dipengaruhi gaya hidup seperti seringnya mengkonsumsi makanan siap saji dan juga usia (proses penuaan) [2].

Beberapa jenis penyakit degeneratif menempati peringkat 10 besar diantaranya: penyakit jantung, asam urat, diabetes mellitus, hipertensi dan lainnya memaksa penderita harus rawat inap ataupun rawat jalan di rumah sakit atau puskesmas [3].
Radikal bebas mengakibatkan stress oksidatif yakni jumlah radikal bebas yang berlebih dalam tubuh mengakibatkan timbulnya penyakit degeneratif karna merusaknya molekul atau jaringan dalam tubuh, juga mengakibatkan penuaan dini karna adanya penurunan kolagen dan elastase pada kulit akibat terpapar radikal bebas. Radikal bebas terdapat dalam tubuh manusia, juga didapatkan dari lingkungan yakni sinar UV, asap rokok, polusi emisi kendaraan, alkohol dan lainnya [4]. Oleh karna itu radikal bebas dalam tubuh harus di seimbangkan supaya tidak memberikan kerusakan lebih banyak.

Buah asam jawa (Tamarindus indica L.) adalah salah satu tanaman yang memiliki berbagai 
khasiat, diantaranya untuk mengobati diare, asma, batuk, demam, sakit panas reumatik, morbili, sariawan, luka baru, alergi, sariawan, eksim dan sebagainya [5].

Masyarakat pulau Lombok memanfaatkan buah asam jawa sebagai tambahan bumbu masakan seperti pada masakan bebalung, sebagai sambal asam jawa muda yang disebut sambel bagek dan sebagian yang lain mengkonsumsi secara langsung buah asam jawa muda, juga sebagai obat tradisional, akan tetapi pemanfaatannya hanya terbatas sampai sana dan bahkan menjadi limbah [6] karna dibiarkan jatuh dan membusuk, padahal pertumbuhan bakteri dapat dihambat dengan memanfaatkan bahan-bahan alam, seperti buah asam jawa yang mengandung daya antibakteri dan senyawa antioksidan [7].

Mencegah efek negatif dari radikal bebas yakni dengan senyawa antioksidan, antioksidan mampu menetralisir peningkatan radikal bebas, antioksidan mampu menunda, memperlambat, mencegah terjadinya oksidasi hingga menghambat reaksi berantai pembentukan radikal bebas dalam tubuh [8]. Buah asam jawa (Tamarindus indica L.) memiliki manfaat sebagai antioksidan yang dapat menghancurkan radikal bebas yang dapat mencegah kerusakan sel [9]. Dalam penelitian ini pegujian antioksidan menggunakan metode DPPH dikarnakan penggunaannya cepat, sederhana, dan tidak memerlukan reagen kimia yang cukup banyak, juga cukup akurat untuk menguji aktivitas antioksidan pada tanaman obat dan ekstrak bahan alam.

\section{METODE PENELITIAN \\ Bahan dan Alat}

Buah Asam Jawa muda dan tua di petik langsung dari pohonnya di Desa Tempos Kecamatan Gerung, Lombok Barat. Beberapa bahan kimia yang digunakan dalam penelitian ini adalah etanol $\left(\mathrm{C}_{2} \mathrm{H}_{5} \mathrm{OH}\right)$, metanol $\left(\mathrm{CH}_{3} \mathrm{OH}\right)$, aquades dan DPPH. Alat yang digunakan adalah alat-alat gelas Laboratorium, mortar, porselen, vortex, pipet ukur, rotary evaporator, timbangan analitik digital, kertas saring, aluminium foil dan spektofotometer UV-Vis.

\section{Preparasi Sampel}

Buah Asam Jawa muda dan tua yang segar dipotong-potong kemudian dioven dengan suhu $40^{\circ} \mathrm{C}-$ $47^{\circ} \mathrm{C}$ selama $7 \times 24$ jam. Setelah itu, masing-masing sampel dihaluskan menggunakan blender hingga menjadi serbuk

\section{Pembuatan Ekstrak Buah Asam Jawa}

Buah asam jawa muda dan tua yang telah menjadi serbuk diekstraksi dengan metode maserasi menggunakan pelarut etanol 96\%. Masing-masing serbuk sampel sebanyak 16 gr dimasukkan ke dalam erlenmayer, kemudian dicampur dengan $100 \mathrm{ml}$ etanol $96 \%$ sebagai pelarutnya. Diamkan selama $3 \times 24$ jam dengan pengadukan beberapa kali. Setelah itu, hasil maserasi di saring menggunakan kertas saring untuk menghasilkan ekstrak cair yang kemudian diuapkan dengan rotary evaporator pada suhu $40^{\circ} \mathrm{C}$ sampai dihasilkan ekstrak kental. Sampel asam jawa muda dan tua memiliki perlakuan yang sama

\section{Uji Aktivitas Antioksidan}

Langkah awal yakni membuat konsentrasi ekstrak buah asam jawa muda dan tua menjadi $0,5 \%$ dengan mengambil masing-masing ekstrak sebanyak $0,5 \mathrm{mg}$, lalu memasukkannya dalam erlenmayer dan dicampur dengan methanol sebanyak $9,5 \mathrm{mg}$, aduk hingga homogen. Kemudian saring keduanya dengan kertas saring untuk menghilangkan residu dengan filtrat. Setelah itu, ambil sebanyak $1 \mathrm{ml}$ dari masingmasing ekstrak $0,5 \%$ tua dan muda, masukkan dalam tabung reaksi yang berbeda, lalu campurkan dengan DPPH, dikocok hingga homogen, tutup dengan aluminium foil, kemudian diinkubasi dalam ruang gelap selama 30 menit dengan suhu ruang. Serapan diukur dengan spektrofotometer UV-Vis pada panjang gelombang $517 \mathrm{~nm}$.

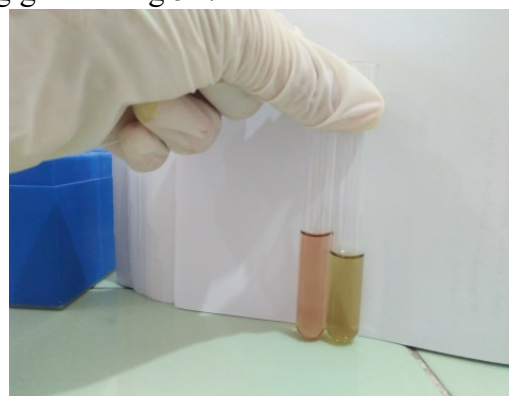

Gambar 2. Pengujian antioksidan dengan DPPH

\section{Analisis Data}

Data yang telah diperoleh dari nilai serapan untuk diuji aktivitas antioksidan selanjutnya aktivitas antioksidan dihitung sebagai persentase berkurangnya warna DPPH dengan menggunakan persamaan:

$$
\% \text { inhibisi }=\frac{A-B}{A} \times 100
$$

A adalah Serapan blangko, sedangkan B adalah serapan sampel

\section{HASIL DAN PEMBAHASAN}

Penelitian ini menggunakan sampel buah asam jawa muda dan tua yang segar. Buah asam jawa muda dan tua diekstrasi dengan metode maserasi menggunakan pelarut etanol 96\%. Setelah dilakukan ekstraksi pada masing-masing sampel kemudian dilakukan pengujian antioksidan dengan metode yang paling umum digunakan dalam uji antioksidan yakni uji DPPH. Metode ini penggunaannya cepat, sederhana, dan tidak memerlukan reagen kimia yang cukup banyak [10]. Uji aktivitas antioksidan buah asam jawa dilakukan dengan mengukur serapan aktivitas hambatan simplisia terhadap radikal bebas DPPH menggunakan spektrofotometer UV-Vis.

Hasil pengujian antioksidan dari buah asam jawa muda dan tua bisa dilihat pada tabel 1 . 
Tabel 1. Hasil Uji Antioksidan Buah Asam Jawa Muda dan Tua

\begin{tabular}{ccc}
\hline No & Sampel & Kadar Antioksidan (\%) \\
\hline 1 & Asam Jawa Muda & 85,28 \\
2 & Asam Jawa Tua & 78,87 \\
\hline
\end{tabular}

Berdasarkan tabel 1 bahwa buah asam jawa yang tua memiliki kadar antioksidan lebih tinggi jika dibandingkan dengan buah asam jawa yang muda. Tubuh manusia selalu memproduksi antioksidan alami, namun jumlah yang dibutuhkan tubuh untuk menyeimbangi oksidan melebihi kemampuan produksi tubuh, oleh karena itu tubuh memerlukan antioksidan tambahan dari luar. Antioksidan yang didapatkan dari luar tubuh dapat diperoleh dari yang alami maupun sintetik, namun penggunaan antioksidan sintetik yang melebihi batas dapat menyebabkan racun, sedangkan yang alami dapat diperoleh dari tumbuh-tumbuhan karna tumbuhan juga salah satu sumber potensial antioksidan alami [11]. Buah asam jawa muda maupun tua bisa dijadikan sebagai antioksidan alami, karna tumbuhan juga salah satu sumber potensial antioksidan alami.

\section{KESIMPULAN}

Berdasarkan hasil penelitian bahwa buah asam jawa (Tamarindus indica L.) memiliki kandungan antioksidan baik yang muda maupun tua. Kadar antioksidan buah asam jawa yang tua lebih tinggi yakni $85,28 \%$, sedangkan buah asam jawa yang muda $78,87 \%$.

\section{DAFTAR PUSTAKA}

[1] Manongko, P. S., Sangi, M. S., Momuat, L. I. (2020). Uji Senyawa Fitokimia dan Antioksidan Tanaman PAtah Tulang (Euphorbia tirucalli L.). Jurnal MIPA. 9(2) 64-69.

[2] Dwisatyadini, M. (2017). Pemanfaatan Tanaman Obat Untuk Pencegahan dan Pengobatan Penyakit Degeneratif. Optimalisasi Peran Sains dan Teknologi untuk Mewujudkan Smart City. Universitas Terbuka Repository.

[3] Hasby., Mauliza., Mastura. (2019). Pemanfaatan Tanaman Obat Sebagai Pencegahan Penyakit Degeneratif. JPPM (Jurnal Pengabdian dan Pemberdayaan Masyaakat). Vol. 3. No. 1.

[4] Wulansari, A. N. 2018. Alternatif Cantigi Ungu (Vaccinium varingiaefolium) Sebagai Antioksidan Alami: Reviuw. Fakultas Farmasi Universitas Padjadjaran. Farmaka, Suplemen Volume 16 Nomer 2.

[5] Imrawati., Baitz, M., Jannah, M. (2016). Uji Antioksidan Ekstrak Etanol Daging Buah Asam (Tamarindus indica L.) Asal Kota Bima Nusa Tenggara Barat Dengan Metode DPPH. Makassar. Journal of Pharmaceutical and Medicinal Sciences 1(2): pp 75-78.

[6] Winaningsih, I., Sita, P. A., Prasetyo, J. A. 2019. Potensi Tamarin Lokal sebagai Pengganti Tamarin Komersial dan Emulsi pada Pencapan Poliester. Akademi Komunitas Negeri Kajen PDD Politeknik
Negeri Bandung. Arena Tekstil Vol. 34 No.1, 2019:15-24.

[7] Muthia, R., Saputri, R., Verawati, S. A. (2019). Uji Aktivitas Antioksidan Ekstrak Etanol Kulit Buah Mundar (Garcinia forbesii King) Menggunakan Metode DPPH (2,2-Diphenyl-1Picrylhydrazil). Jurnal Pharmascience. Vol. 06, No. 01. 74-82.

[8] Paputungan, Z., Wonggo, D., Kaseger, B. E. (2017). Uji Fitokimia dan Aktivitas Antioksidan Buah Mangrove Sonneatia alba Di Desa Nunuk Kecamatan Pinolosian Kabupaten Bolaang Mongondow Selatan. Jurnal Media Teknologi Hasil Perikanan Vol. 5. No. 3.

[9] Makrufa, W. N. (2019). Pemanfaatan Asam Jawa (Tamarindus indica) untuk Menurunkan Kadar Glukosa Darah Pada Diabetes Melitus. Jurnal Ilmu Kedokteran Dan Kesehatan, Vol. 6. No. 3.

[10] Muthia, R., Saputri, R., Verawati, S. A. (2019). Uji Aktivitas Antioksidan Ekstrak Etanol Kulit Buah Mundar (Garcinia forbesii King) Menggunakan Metode DPPH (2,2-Diphenyl-1Picrylhydrazil). Jurnal Pharmascience. Vol. 06, No. 01. 74-82.

[11] Poliester. Akademi Komunitas Negeri Kajen PDD Politeknik Negeri Bandung. Arena Tekstil Vol. 34 No.1, 2019:15-24 